\title{
Segmentation by motivation of tourists to the Kgalagadi Transfrontier Park
}

\author{
M. Saayman* and T. Dieske \\ TREES (Tourism Research in Economic Environs and Society), North-West University, Potchefstroom, South Africa \\ *To whom all correspondence should be addressed \\ Melville.Saayman@nwu.ac.za
}

\begin{abstract}
The Kgalagadi Transfrontier Park is one of South Africa's unique attractions for national and international tourists. However, little research has been done on visitors to transfrontier parks. In addition marketers highlight the importance of understanding the reasons why people travel and who these tourists are. Therefore the aim of this article is to segment the market of the Kgalagadi Transfrontier Park by means of visitors' travel motives. This was achieved by means of a survey. In the statistical analysis, 414 questionnaires were used and the survey was conducted from 2010 to 2012 . The statistical analysis included a factor analysis and ANOVA. Four factors were identified through the factor analysis namely escape, education and recreation, park attributes and exploration. The latter was unique to this research since it has not been found in other studies. The ANOVA confirmed that a wide variety of variables influence the decision-making process and that the marketing strategy should focus on different methods and events to attract a greater market.
\end{abstract}

\section{Introduction}

Africa's reserves and national parks are main attractions drawing international tourists to the continent. The Kgalagadi Transfrontier Park is one of such areas, which is an amalgamation of South Africa's former Kalahari Gemsbok National Park and Botswana's Gemsbok National Park (SANParks, 2012:2). With the official opening of the park on the $12^{\text {th }}$ May 2000 it represents the first formally declared transfrontier park in Africa (SANParks, 2012:2) that aims at returning ecosystems into their natural state by overcoming political borders (Hanks, 2003:127). The combined land area comprises about $38,000 \mathrm{~km}^{2}$ (SAvenues, 2012) which is nearly twice the size of the Kruger National Park (see Map 1). Besides the location and the magnitude of the park, its flora and fauna augments the uniqueness and makes the area of special value to conservation (SANParks, 2012:2).

However research conducted by Kruger and Saayman (2010:94) found that target markets main motives differ from one national park to another, which implies that one marketing strategy cannot be used for all parks in a country or even a region. Kruger \& Saayman (2010:94) state that it is important to understand the visitors and their specific needs in order to develop adequate marketing strategies and address their needs. Therefore, the aim of this paper is to segment the visitors of the Kgalagadi Tranfrontier Park by means of travel motives. This would allow Park management to focus its resources on the right market (Wood, 2011:66). From a competitive point of view, South Africa has 22 national parks including three transfrontier parks, as well as several local and provincial parks and in addition 9000 privately owned game reserves competing for national and international tourists (Saayman \& van der
Merwe, 2004). Hence, competition is increasing and understanding tourist's reasons for visiting becomes more important in developing successful nature-based products.

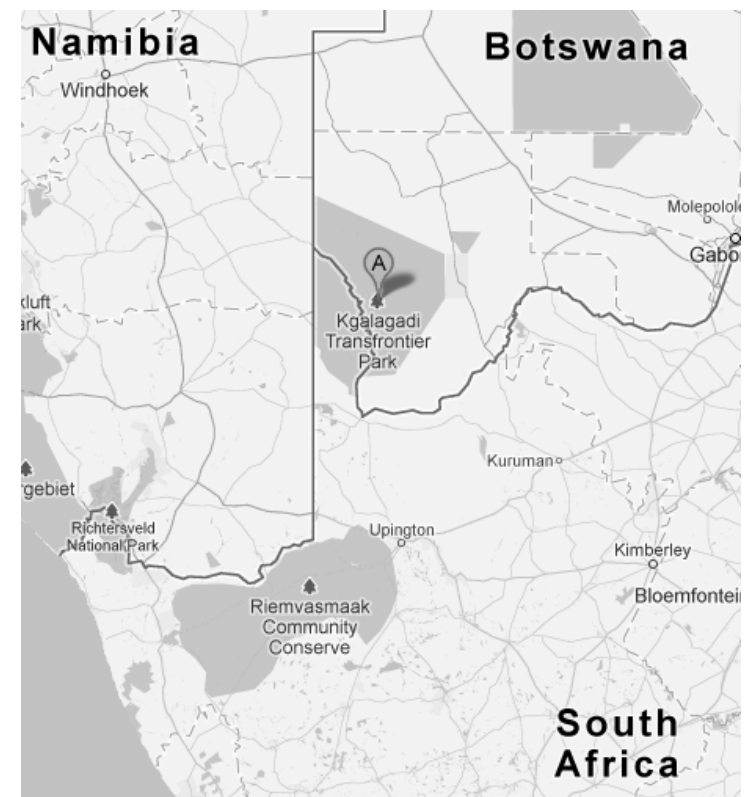

Map 1: Kgalagadi Transfrontier Park

\section{Source: Google Maps}

Wood (2011:66) states that a detailed knowledge of the target group including tourists wants and needs is the basis for improving the marketing efficiency and effectiveness. Thereby it is possible to give the Transfrontier Park a distinctive and meaningful position on the market of national parks and in the minds of the targeted visitors. 


\section{Literature review}

According to McDonald and Dunbar (2004:124) market segmentation describes "the process of splitting customers, or potential customers, within a market into different groups, or segments, within which customers share a similar level of interest in the same, or comparable, set of needs satisfied by a distinct marketing proposition".

These researchers also state that the effectiveness of market segmentation depends on identifying segments that are measurable, accessible, substantial, actionable and differentiable. Finding such segments enables a closer matching of customers' needs by recognizing and understanding their differences. Thus, this knowledge gives strategic direction for target markets and positioning and helps to focus scarce resources required to create a competitive advantage by considering the market in a different way than the competitors (McDonald \& Dunbar, 2004:55). However, most of the segment bases used in tourism related research are a combination of sociodemographic and behavioural variables, as shown in Figure 1 (Kruger \& Saayman, 2010:94). A review of 120 research papers by Tkaczynski and Rundle-Thiele (2011) confirms this notion.

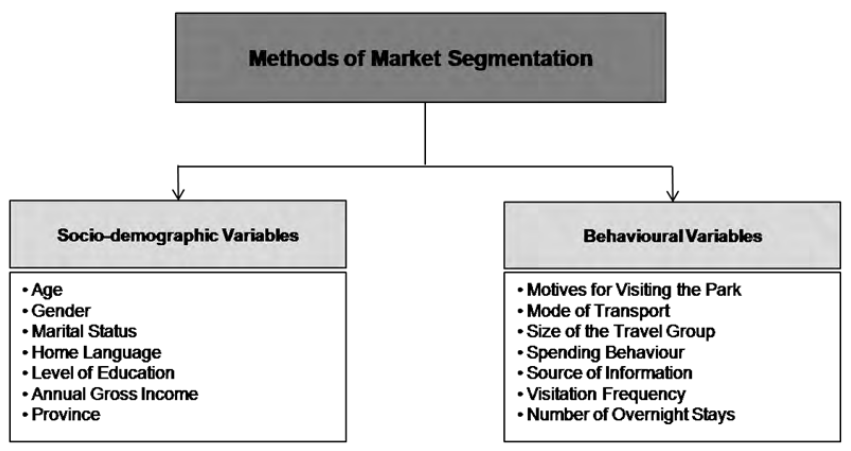

Figure 1: Market segmentation by means of sociodemographic \& behavioural variables

Source: Authors own illustration based on the literature review

In tourism literature aspects such as behaviour, patterns, motivation and benefits sought of nature-based/ national park tourists, and their interrelation have not been considered in great detail (Kruger \& Saayman, 2010:94; Park \& Yoon, 2009:100). Furthermore, variables describing demographic and socio-economic characteristics have often been used as basis of segmentation, but drawing predictive conclusions in terms of the relation between e.g. age, gender, income and purchase behaviour strongly depends on the situation and cannot be generalized because there is only an indirect relation between those (Park \& Yoon, 2009:100).

Segmenting by means of behavioural variables as usage rates, loyalty levels and benefit sought is the process to cluster customers and potential ones according to their understanding of, uses for and responses on products and services (Venter \& Jansen van Rensburg: 2009:147). This approach is of limited use when customers are clustered due to their buying or usage behaviour of products or services without understanding the reasons and motivations for their actions (Venter \& Jansen van Rensburg, 2009:147). Thus, more and more marketers see the analysis of the travel behaviour itself, including the benefits and motivations as the most effective way to predict tourists' behaviour (Park \& Yoon, 2009:100; Goeldner \& Ritchie, 2003; Johns \& Gyimothy, 2002; Kotler, Bowen, \& Makens, 2003). Research by Lee and Lee (2001) considered segmentation through motivation as a powerful tool that enables managers to identify strengths and opportunities of each market. Based on this, it facilitates the process to enhance and promote the product features preferred and valued by the targeted customers. Regarding the advantages of segmentation by means of visitors' motivation, this method is applied in the present research with the aim to draw conclusions on the behaviour, preferences and needs of visitors to the Kgalagadi Transfrontier Park.

Past research has demonstrated that the identification of tourist motivations can be a functional and effective method to determine adequate visitor opportunities and in addition, to identify homogenous segments out of a pool of heterogeneous tourists (Awaritefe, 2003a, b; Beh \& Bruyere, 2007; Keng \& Cheng, 1999; Poria, Butler \& Airey, 2004). Therefore to provide a unique tourism experience that satisfies the visitors' needs and wants and simultaneously, to market it actively, it is essential to be aware of tourists' travel motivation (Beh \& Bruyere, 2007; Fodness, 1994; Kruger \& Saayman, 2010).

Motivation is understood as the underlying force that occurs and influences human beings' behaviour (Beh \& Bruyere, 2007:1464; Iso-Ahola, 1999). Therefore, behaviour can be seen as a process that aims at satisfying internal psychological factors as needs and desires which can cause tension to some extent that has to be released through certain action (Beh \& Bruyere, 2007:1464; Fodness, 1994). In the case of tourism activities, Lubbe (1998) sees the beginning of motivation at that time an individual becomes aware of certain needs and wishes and perceives that a specific destination or attraction could satisfy those needs. Thus, making the decision of travelling to a certain area (in this case a national park) is an attempt to meet certain needs and wants (Beh \& Bruyere, 2007:1465; Crompton, 1979; Crompton \& McKay, 1997; Fodness, 1994; Lohmann, 2004; Kruger \& Saayman, 2010:94). According to Qu and Ping (1999) tourists who visit the same (national) park may even satisfy individual needs and may derive different benefits.

The travel behaviour of tourists is influenced by the person's motivation which can embrace more than one motive at one time (Mill \& Morrision, 1985). In tourism research different motivational factors have been examined and is summarized as follows: escape (Crompton, 1979); adrenalin/excitement seeking (Loker \& Perdue, 1992); self-enhancement (Fodness, 1994); socializing (Backman, Backman, Uysal \& Sunshine, 1995); safety/comfort (Oh, Uysal \& Weaver, 1995); family togetherness (Schneider \& Backmann, 1996); 
culture exploration (Lee, Lee \& Wicks, 2004); education (Bansal \& Eislet, 2004); health and fitness (Swanson \& Horridge, 2006); facilities, events and cost (Jang \& Wu, 2006) and nature (Molera \& Albaladejo, 2007).

Looking at the travel motivation of visitors to national parks limited research has been done (Kruger \& Saayman, 2010:942). In 2010 Kruger and Saayman analyzed studies from 1994 to 2009 on travel motives to national parks/nature areas and up to now new research have been conducted by Jun, Kyle and Mowen (2009), Dey and Sarma (2010), Lee (2009), Lili, Lijuan and Ming (2010), Slabbert and Laurens (2011), and Line and Costen (2011). The results from the respective studies are illustrated in Table 1 and several conclusions can be drawn.

Firstly, the fact that 21 motivational factors were revealed, indicates that different visitors to different parks/nature areas have different motives (Pan \& Ryan, 2007). Thus, the hypothesis can be made that visitors have different motives visiting a national park because parks differ in what is on (1) offer, (2) its location, (3) type of market and (4) type of activities (Kruger \& Saayman, 2010:94). Therefore, by identifying the motives of tourists travelling to a specific national park, those factors can be considered by planning marketing strategies and marketing can be applied more effectively (Saayman, 2006).

Secondly, by examining and comparing the studies focusing on tourists to national parks/nature areas, motivational factors reoccur. As Kruger \& Saayman already pointed out in their research in 2010, the most consistent motive is education/ learning about nature. Then, out of 15 studies (see Table 1), eight found that tourists are motivated in terms of participation in recreation activities/ recreation or leisure pursuits, as well as nature and social contact/enhancement of kinship relations. Thus, these motives can be seen as the most common for travelling to a national park/ nature area.

Thirdly, it can be perceived that motives such as escape and relaxation are not the most consistent in first place in the case of visiting a national park/nature-based area. This finding is surprising considering the fact that these motives are the most common ones found in the tourism literature. Hence, visitors to national parks/ nature-based areas cannot be treated as a homogenous segment because their motives and as a consequence also their behaviour, needs and wants are complex and varying (Kruger \& Saayman, 2010:94).

\section{Table 1: Analysis of research on travel motives to National Parks/Nature Areas}

\begin{tabular}{|c|c|c|c|c|c|c|c|c|c|c|c|c|c|c|c|}
\hline 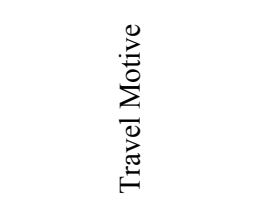 & 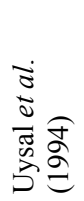 & 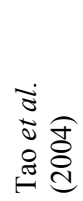 & 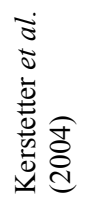 & : & 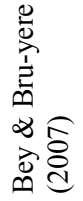 & 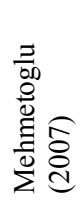 & 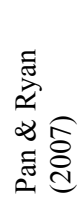 & 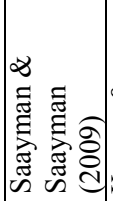 & 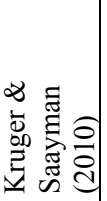 & 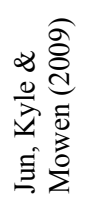 & 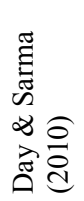 & 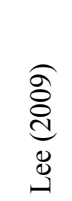 & 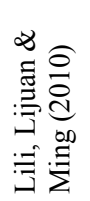 & 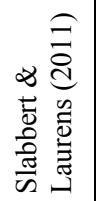 & 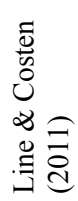 \\
\hline Relaxation (6) & $\mathrm{x}$ & & & & & & $\mathrm{x}$ & & $\mathrm{x}$ & & $\mathrm{x}$ & $\mathrm{x}$ & & $\mathrm{x}$ & \\
\hline Novelty (5) & $\mathrm{x}$ & & & & & $\mathrm{x}$ & & & & & & $\mathrm{x}$ & & $\mathrm{x}$ & $\mathrm{x}$ \\
\hline Escape (6) & $\mathrm{x}$ & & & & $\mathrm{x}$ & & & $\mathrm{x}$ & $\mathrm{x}$ & & $\mathrm{x}$ & & & & $\mathrm{x}$ \\
\hline Prestige (1) & $\mathrm{x}$ & & & & & & & & & & & & & & \\
\hline $\begin{array}{l}\text { Education/Learning } \\
\text { about nature (13) }\end{array}$ & & $\mathrm{x}$ & $\mathrm{x}$ & $\mathrm{x}$ & $\mathrm{x}$ & $\mathrm{x}$ & $\mathrm{x}$ & & $\mathrm{x}$ & $\mathrm{x}$ & $\mathrm{x}$ & $\mathrm{x}$ & $\mathrm{x}$ & $\mathrm{x}$ & $\mathrm{x}$ \\
\hline $\begin{array}{l}\text { Participation in } \\
\text { recreation/Recreation } \\
\text { or leisure pursuits }(8)\end{array}$ & & $\mathrm{x}$ & & $\mathrm{x}$ & & $\mathrm{x}$ & & $\mathrm{x}$ & & $\mathrm{x}$ & & $\mathrm{x}$ & $\mathrm{x}$ & & $\mathrm{x}$ \\
\hline Adventure (3) & & & $\mathrm{x}$ & & $\mathrm{x}$ & & & & & & $\mathrm{x}$ & & & & \\
\hline Holistic (1) & & & $\mathrm{x}$ & & & & & & & & & & & & \\
\hline Self actualizing (5) & & & & $\mathrm{x}$ & $\mathrm{x}$ & $\mathrm{x}$ & $\mathrm{x}$ & & & & & & & $\mathrm{x}$ & \\
\hline Culture (2) & & & & $\mathrm{x}$ & $\mathrm{x}$ & & & & & & & & & & \\
\hline Nature (8) & & & & & $\mathrm{x}$ & $\mathrm{x}$ & & $\mathrm{x}$ & $\mathrm{x}$ & $\mathrm{x}$ & & $\mathrm{x}$ & $\mathrm{x}$ & & $\mathrm{x}$ \\
\hline Game viewing (2) & & & & & $\mathrm{x}$ & & & & & & & $\mathrm{x}$ & & & \\
\hline $\begin{array}{l}\text { Mundane everyday } \\
\text { (1) }\end{array}$ & & & & & & $\mathrm{x}$ & & & & & & & & & \\
\hline $\begin{array}{l}\text { Social } \\
\text { contact/Enhancement } \\
\text { of kinship relations } \\
\text { (8) }\end{array}$ & $\mathrm{x}$ & & & & & $\mathrm{x}$ & $\mathrm{x}$ & $\mathrm{x}$ & & $\mathrm{x}$ & $\mathrm{x}$ & $\mathrm{x}$ & $\mathrm{x}$ & & \\
\hline Attractions (1) & & & & & & & & $\mathrm{x}$ & & & & & & & \\
\hline Photography (1) & & & & & & & & $\mathrm{x}$ & $\mathrm{x}$ & & & & & & \\
\hline Activity/Fun (3) & & & & & & & & & & $\mathrm{x}$ & $\mathrm{x}$ & & & & \\
\hline Park attributes (2) & & & & & & & & & $\mathrm{x}$ & & & & & $\mathrm{x}$ & \\
\hline $\begin{array}{l}\text { Interpersonal } \\
\text { motivators (1) }\end{array}$ & & & & & & & & & & & & & & $\mathrm{x}$ & \\
\hline Nostalgia (1) & & & & & & & & & $\mathrm{x}$ & & & & & & \\
\hline
\end{tabular}

Source: adapted from Kruger and Saayman, 2010:3 
In conclusion the literature review confirms that only a few studies of this kind have been done and that more of such research is required.

\section{Methododology}

A structured consumer-based questionnaire was administered from 2010 to 2012 to gather data from visitors to the Kgalagadi Transfrontier Park. The method of research is described under the headings (1) The Questionnaire, (2) The Sample and (3) The Method.

\section{The questionnaire}

The questionnaire that was used to conduct the survey remained similar throughout the period (2010 to 2012) of data collection and was divided into five sections and based on research conducted by Van der Merwe and Saayman (2008) and Kruger, Saayman and Saayman (2009). Section A asked for information on socio-demographic variables, for example, gender, age, marital status, level of education and province of origin. Section B captured visitors' spending behaviour as number of persons paid for, frequency of visits, length of stay and amount of spent. Section $\mathrm{C}$ focused on travel motivational factors where 17 items were measured on a 5-point Likert scale $(1=$ not at all important; $2=$ slightly important; 3 = important; 4 = very important and 5 $=$ extremely important). In Section $\mathrm{D}$, information about consumer's general behaviour was surveyed, for example preferences concerning their visit of the national park or evaluating their experiences with specific camps. Section E serves to receive the visitors' evaluation of park specific attributes, measured on a 6 -point Likert scale $(1=$ very poor; $2=$ poor; $3=$ fair; $4=$ good; $5=$ Excellent and $6=$ Not applicable). For the purpose of this article, the information captured from section A to $\mathrm{C}$ was predominantly used.

\section{The sample}

The surveys were conducted annually between 2010 and 2012 in the Kgalagadi Transfrontier Park and Table 2 gives information about the sample sizes. From this it can be seen that over the survey period a consistent number of questionnaires have been conducted $(\sim 138)$ and a total of 414 questionnaires was administered.

\section{Table 2: Total number of questionnaires completed}

\begin{tabular}{l|c|c|c|c}
\hline Year & $\mathbf{2 0 1 0}$ & $\mathbf{2 0 1 1}$ & $\mathbf{2 0 1 2}$ & Total \\
\hline $\begin{array}{l}\text { Number of } \\
\text { questionnaires }\end{array}$ & 149 & 127 & 138 & 414 \\
\hline $\begin{array}{l}\text { *Each questionnaire completed represents one travelling group consisting } \\
\text { of three persons }\end{array}$
\end{tabular}

All visitors that participated in the survey received a questionnaire to complete on their own and field workers collected it during the evenings or early mornings. As a tourist can be considered as a person who voluntarily leaves his normal abode to visit a place for a period more than 24 hours (Kruger \& Saayman, 2010), only overnight-visitors have been taken into account within this survey.
By looking at the sample size the following aspects have to be considered: Firstly, one questionnaire was distributed to the person who represents a travelling group (usually a family) of which the average is about three people. Secondly, the Kgalagadi Transfrontier Park has only a few small lodges and camps (accommodation) available due to water scarcity. Thirdly, due to the size of the park and the fact that the lodges are dispersed, the research team could not access more than one camp per day since the surveys took place at night. Furthermore, the tourists also travel from camp to camp which complicates the survey since they can only participate once. Therefore, conducting a survey within this park is expensive and time consuming. 29,903 people visited the park in 2012. The 414 questionnaires represented families or traveling groups that consisted on average of 3 people. Therefore this survey represented 1242 visitors to the Park, which is a sufficient number or sample size even when one looks over a three year period (Krejcie \& Morgan, 1970).

\section{Data analysis}

Microsoft Excel ${ }^{\circledR}$ was used to capture data and the analysis included a factor analysis with Kaiser's criterion concerning the motivations was undertaken through SPSS to describe covariance relationships among the 17 motivation items and to group them into 'factors' according to their correlation (Johnson \& Wichern, 2002). Thereafter a T-Test was undertaken to assess the equality of variances in the samples classified by their motivation. Subsequently, ANOVAs were used to identify the differences between the respondents on the basis of their socio-demographic characteristics and their motives for visiting the Kgalagadi Transfrontier Park. In addition, the Spearman's correlation coefficient was applied to identify if there are any associations between the four motivational factors and other variables and if so, the aim was to identify to which magnitude and direction the identified associations are characterized.

\section{Results}

\section{Factor analysis of travel motivation to the Kgalagadi Transfrontier Park}

The factor analysis (Pattern Matrix) of the Kgalagadi Transfrontier Park identified four factors accounted for $62.5 \%$ of the total variance (Table 3 ). The factors are formulated as 'Park attributes', 'Escape', 'Education \& Recreation' and 'Exploration'. The first factor named 'Park attributes' consists of eight items, namely 'I prefer the Park for it geographical features', 'I prefer the park due to its remoteness and few tourists', 'It is an ideal holiday destination', 'I have a preference for the Kalahari', 'I am loyal to the park', 'The park has excellent $4 \times 4$ ', 'It is value for money' and 'It is a spiritual experience'. The second factor 'Escape' is formed through the dimensions 'To relax' and 'To get away from routine' which all show loading greater than .50. The factor 'Education \& Recreation' includes the motivational items 'So that other members in my party could learn about nature' and 'For family 
recreation or to spend time with someone special'. Factor four 'Exploration' is formed by the items 'To spend time with friends' and 'To explore a new destination'.

Table 3: Factor analysis (pattern matrix) for the Kgalagadi Transfrontier Park

\begin{tabular}{|c|c|c|c|c|}
\hline Factor Labels & $\begin{array}{l}\text { F1 } \\
\text { Park Attributes }\end{array}$ & $\begin{array}{l}\text { F2 } \\
\text { Escape }\end{array}$ & $\begin{array}{l}\text { F3 } \\
\text { Education \& } \\
\text { Recreation } \\
\end{array}$ & $\begin{array}{l}\text { F4 } \\
\text { Exploration }\end{array}$ \\
\hline Mean values & 3.335 & 4.052 & 3.630 & 3.393 \\
\hline I prefer the Park for it geographical features & .767 & & & \\
\hline I prefer the park due to its remoteness and few tourists & .671 & & & \\
\hline It is an ideal holiday destination & .658 & & & \\
\hline I have a preference for the Kalahari & .627 & & & \\
\hline I am loyal to the Park & .621 & & & \\
\hline The Park has excellent $4 x 4$ & .600 & & & \\
\hline It is value for money & .451 & & & \\
\hline It is a spiritual experience & .324 & & & \\
\hline To relax & & .771 & & \\
\hline To get away from routine & & .675 & & \\
\hline So that other members in my party could learn about nature & & & .739 & \\
\hline For family recreation or to spend time with someone special & & & .542 & \\
\hline To spend time with friends & & & & .402 \\
\hline To explore a new destination & & & & .387 \\
\hline Cronbach's Alpha & 0.838 & 0.770 & 0.647 & 0.451 \\
\hline
\end{tabular}

T-Test for Equality of Means

After the factor analysis was conducted the T-Test for Equality of Means was undertaken to assess the equality of variances in the samples classified by their motivation. By testing the null hypothesis it is assumed that variances of the different groups are equal which is called homogeneity of variance. If the $p$-value is significant $(\leq 0.05)$ the null hypothesis is rejected which means that there is a difference between the variances in the population.

Table 4: T-test for equality of means

\begin{tabular}{|c|c|c|c|c|c|}
\hline & & $\begin{array}{l}\text { F1 } \\
\text { Park attributes }\end{array}$ & $\begin{array}{l}\text { F2 } \\
\text { Escape }\end{array}$ & $\begin{array}{l}\text { F3 } \\
\text { Education } \\
\text { Recreation }\end{array}$ & $\begin{array}{l}\text { F4 } \\
\text { Exploration }\end{array}$ \\
\hline Gender & & 0.274 & 0.899 & 0.892 & $0.059 *$ \\
\hline \multirow{8}{*}{ Source of information } & Website & 0.944 & 0.794 & 0.931 & $0.047 *$ \\
\hline & Shows & 0.163 & 0.878 & 0.970 & $0.012 *$ \\
\hline & Radio & 0.576 & 0.897 & 0.660 & 0.272 \\
\hline & TV & $0.019 *$ & 0.268 & 0.242 & $0.014 *$ \\
\hline & Magazines & $0.052 *$ & $0.000^{*}$ & 0.384 & $0.016^{*}$ \\
\hline & SANParks & 0.710 & $0.048 *$ & 0.873 & $0.077 *$ \\
\hline & Friends & 0.217 & 0.428 & 0.241 & $0.000 *$ \\
\hline & Previous visits & $0.006 *$ & 0.101 & $0.005^{*}$ & $0.001 *$ \\
\hline Wild Card Holder & & $0.024 *$ & $0.041 *$ & $0.067 *$ & $0.055^{*}$ \\
\hline $\begin{array}{l}\text { Accompanying } \\
\text { children }\end{array}$ & & 0.875 & $0.046^{*}$ & $0.000^{*}$ & 0.944 \\
\hline
\end{tabular}

* Statistically significant: $\mathrm{p} \leq .05$

Thus, by looking at the significance values in Table 4 the further explanation is still statistically significant concerning gender, it becomes clear that females are more motivated by the factor of 'Exploration' than men. With regard to the source of information visitors who used the website for information purposes are more interested in the factor 'Exploration' (mean value 3.54) than the visitors who did not (mean value 3.28). Furthermore, visitors who attend shows as information source about the Kgalagadi Transfrontier Park were also more motivated by the factor of 'Exploration' (mean value 3.81) than people who did not (mean value 3.32 ). Visitors who were informed by television were more motivated by the factors 'Park attributes' (mean value 3.66) and 'Exploration' (mean value 3.80 ) than those who were not informed by television (mean value 3.24 and 3.31 respectively). Noteworthy, there were high significances in the difference of variances found concerning visitors who have used magazines as a source of information. These tourists were more motivated by factor one, two and four, except for the third factor 'Education \& Recreation'. No significances were found here, which means unless they have read magazines or not, there are no significant differences if they are more or less motivated by this factor. 
Tourists who were informed by means of SANParks have a higher motivation in terms of 'Exploration' (mean value 3.55) and 'Escape' (mean value 4.18) than those who did not (mean value 3.29 and 3.93 respectively). There is a high significant difference in variances within the group of visitors who were informed by means of friends due to their high motivation by the factor 'Exploration' (mean value 3.61) and the same applies for previous visits to the Kgalagadi Transfrontier Park as information source which had a higher mean value of 3.46 within the motivation factor 'Park attributes' and 'Education \& Recreation' (mean value 3.83). A plausible finding is also that tourists who used previous visits to the Park as information source are not as much motivated to explore the Park (mean value 3.10) as they already know the park than people who did not use previous visits (mean value 3.56).

Tourists with a Wild Card (loyalty card) showed significant differences in all motivational factors. With respect to the mean values, it is noticeable that people who are a Wild Card holder have a higher mean value in factor one to three which means there is a higher motivation of Wild Card holders by 'Park attributes', 'Escape' and 'Education \& Recreation'. Tourists who do not own a Wild Card show a higher mean value of 3.57 for 'Exploration' than Wild Card holders (mean value 3.32).

Tourists who were accompanied by their children were more motivated by 'Escape' (mean value 4.08) than people who travelled without children (mean value 3.83 ).

ANOVAs and Tukey's Post Hoc Multiple Comparisons ANOVAs were used to identify the differences between the respondents on the basis of their socio-demographic characteristics and their motives for visiting the Kgalagadi Transfrontier Park.

As Table 5 illustrates, there were statistically significant differences between the four factors of motivation and these differences are especially pronounced when language $(p<$ $0.001)$ and province of origin $(p<0.001)$ are considered. Only moderate statistically significant differences $(\mathrm{p}<0.1)$ were found between the motivational factors and educational level of respondents. There are differences in three of the four factors when language as a sociodemographic characteristic is considered. Tukey's Post Hoc test indicated that the differences lies between other languages compared to English and Afrikaans.

Table 5: Results of ANOVA multiple comparisons for visitor characteristics $(n=414)$

\begin{tabular}{|c|c|c|c|c|}
\hline Characteristics & F1: Park Attributes & F2: Escape & F3: Education \& Recreation & F4: Exploration \\
\hline \multicolumn{5}{|l|}{ Language } \\
\hline Afrikaans & $3.38^{\mathrm{a}}$ & $4.13^{\mathrm{a}}$ & $3.77^{\mathrm{a}}$ & 3.41 \\
\hline English & $3.35^{\mathrm{a}}$ & $4.09^{\mathrm{a}}$ & $3.63^{\mathrm{a}}$ & 3.41 \\
\hline Other Languages & $2.93^{\mathrm{b}}$ & $3.32^{\mathrm{b}}$ & $2.67^{b}$ & 3.14 \\
\hline F ratio & 3.21 & 8.39 & 11.55 & 0.78 \\
\hline Sig. Level & $0.041^{*}$ & $<0.001^{*}$ & $<0.001^{*}$ & 0.461 \\
\hline \multicolumn{5}{|l|}{ Marital Status } \\
\hline Single & $3.49^{\mathrm{a}}$ & 4.21 & 3.75 & 3.43 \\
\hline Married & 3.26 & 3.98 & 3.60 & 3.33 \\
\hline Living together & $3.01^{\mathrm{b}}$ & 3.97 & 3.39 & 3.53 \\
\hline F ratio & 4.00 & 2.12 & 1.09 & 0.48 \\
\hline Sig. Level & $0.019 *$ & 0.121 & 0.336 & 0.622 \\
\hline \multicolumn{5}{|l|}{ Provinces } \\
\hline Northern Cape & $3.60^{\mathrm{a}}$ & $4.15^{\mathrm{a}}$ & $3.73^{\mathrm{a}}$ & 3.53 \\
\hline Gauteng & 3.34 & 4.03 & $3.72^{\mathrm{a}}$ & 3.55 \\
\hline Eastern Cape & 3.37 & 3.80 & 3.47 & 3.50 \\
\hline North West & $3.67^{\mathrm{a}}$ & $4.39^{\mathrm{a}}$ & $4.00^{\mathrm{a}}$ & 3.38 \\
\hline Mpumalanga & 3.29 & $4.18^{\mathrm{a}}$ & $3.92^{\mathrm{a}}$ & 3.93 \\
\hline Western Cape & 3.30 & $4.17^{\mathrm{a}}$ & $3.67^{\mathrm{a}}$ & 3.21 \\
\hline KwaZulu-Natal & 2.97 & 4.06 & $3.72^{\mathrm{a}}$ & 3.19 \\
\hline Limpopo & 3.43 & $4.19^{\mathrm{a}}$ & $3.96^{\mathrm{a}}$ & 3.62 \\
\hline Free State & $3.73^{\mathrm{a}}$ & $4.19^{\mathrm{a}}$ & $3.58^{\mathrm{a}}$ & 3.42 \\
\hline Outside RSA borders & $2.71^{\mathrm{b}}$ & $3.27^{\mathrm{b}}$ & $2.63^{\mathrm{b}}$ & 3.12 \\
\hline F ratio & 4.79 & 4.43 & 5.02 & 1.35 \\
\hline Sig. Level & $<0.001^{*}$ & $<0.001^{*}$ & $<0.001^{*}$ & 0.209 \\
\hline \multicolumn{5}{|l|}{ Educational level } \\
\hline Matric & 3.53 & 3.97 & 3.70 & 3.89 \\
\hline Diploma/Degree & 3.27 & 4.10 & 3.55 & 3.20 \\
\hline Post-graduate & 3.19 & 4.11 & 3.80 & 3.39 \\
\hline Professional & 3.45 & 4.01 & 3.68 & 3.62 \\
\hline F ratio & 2.32 & 0.38 & 0.83 & 2.36 \\
\hline Sig. Level & 0.075 & 0.768 & 0.480 & 0.071 \\
\hline
\end{tabular}

Note. Respondents were asked to indicate how they evaluated each motivation item on the scale

$(1$ = not important at all; $2=$ slightly important; 3 = important; 4 = very important; 5 = extremely important $)$.

* Statistically significant: $\mathrm{p} \leq .05$. 
Afrikaans- and English speaking tourists tend to be more motivated (mean value 3.38 and 3.35 ) by 'Park attributes' than tourists who speak another language (mean value 2.93). Noteworthy, there are high significant differences $(\mathrm{p}<$ 0.001) in Afrikaans- and English speaking respondents' attraction by the motivational factors of 'Escape' (mean value 4.13 and 4.09) as well as 'Education \& Recreation' (mean value 3.77 and 3.63) than tourists speaking another language.

Regarding marital status, only one significant difference ( $p$ $=0.019$ ) could be found. Tukey's Post Hoc test indicated that the difference lies between tourists visiting the Kgalagadi Transfrontier Park who are single and those who are living together. Single people evaluated the Park's attributes as more important (mean value 3.49) than people who are in the marital status of living together (mean value 3.01).

Concerning the origin of respondents, the ANOVA again indicated that there are significant differences in three of the four factors. The Post Hoc test points out that in all cases, visitors from outside the borders of South Africa score lower on factors one to three than their South African counterparts. This implies that the motivation for visiting the Park differs significantly between foreign and local visitors.

With regard to the educational level moderate statistically significant differences $(\mathrm{p}<0.1)$ were identified. Respondents who have a Diploma/Degree or are postgraduated score lower on the factors 'Park attributes' (mean value 3.27 and 3.29) and 'Exploration' (mean value 3.20 and 3.39) than people with another qualification. Considering the moderate statistically significant differences it can be assumed that visitors, who specified their educational level as 'Professional' or 'Matric', are more attracted by the Park in terms of its 'Park attributes' (mean value 3.45 and 3.53) and the motivation 'Exploration' (mean value 3.62 and 3.89 ).
The Spearman's correlation coefficient was applied to identify if there are any association between the four motivational factors and other variables and if so, through which magnitude and direction is the association characterized. Thus, if significances are determined (at the level of $\mathrm{p}<0.01$ and $\mathrm{p}<0.05$ ) the null hypothesis which indicated that there are no dependencies between two variables is rejected. This means, that there is an association between two variables.

Therefore, Table 6 shows several significant associations between the motivational factors and socio-demographic variables. The first significance $(p<0.05)$ could be identified concerning the visitors' spending behaviour within the Kgalagadi Transfrontier Park. In addition, the correlation coefficient of 0.111 indicates the tendencies that the more visitors spend during their stay in the Park the more motivated are they in terms of factor 'Escape'. Regarding the socio-demographic variable 'age' two significances $(p<0.05)$ were determined. Thus, it shows a small association that the younger the visitors are, more interested in factor two 'Escape' (correlation coefficient 0.154 ) and in factor four 'Exploration' (correlation coefficient -0.113 ) exists.

A significant moderate relation $(\mathrm{p}<0.01)$ were found regarding the correlation coefficient of 0.303 within the variable for how many people the interviewed visitor paid for. Hence, the more people the visitor has to pay for, the higher was his/her motivation to educate and recreate (factor three). Noteworthy, with respect to the variable of annual gross income no significances were identified. By looking at the tourists' overnight visits over the last three years, the significance $(p<0.01)$ and the correlation coefficient of 0.143 indicate that there is a small association. Consequently, the fewer tourists stayed at the Kgalagadi Transfrontier Park as an overnight-guest over the last three years, the more motivated are they to explore the Park (factor four). 
Table 6. Results of Spearman's rho for visitor characteristics $(n=414)$

\begin{tabular}{|c|c|c|c|c|c|}
\hline & $\begin{array}{l}\text { F1 } \\
\text { Park Attributes }\end{array}$ & $\begin{array}{l}\text { F2 } \\
\text { Escape }\end{array}$ & $\begin{array}{l}\text { F3 } \\
\text { Education } \\
\text { Recreation }\end{array}$ & $\&$ & $\begin{array}{l}\text { F4 } \\
\text { Exploration }\end{array}$ \\
\hline \multicolumn{6}{|l|}{ F1 Park Attributes } \\
\hline Correlation Coefficient & 1.000 & $0.473 * *$ & $0.464 * *$ & & $0.291 * *$ \\
\hline Sig. (2-tailed) & & 0.000 & 0.000 & & 0.000 \\
\hline $\mathrm{N}$ & 398 & 392 & 380 & & 385 \\
\hline \multicolumn{6}{|l|}{ F2 Escape } \\
\hline Correlation Coefficient & $0.473 * *$ & 1.000 & $0.359 * *$ & & $0.312 * *$ \\
\hline Sig. (2-tailed) & 0.000 & & 0.000 & & 0.000 \\
\hline $\mathrm{N}$ & 392 & 395 & 378 & & 385 \\
\hline \multicolumn{6}{|c|}{ F3 Education \& Recreation } \\
\hline Correlation Coefficient & $0.464 * *$ & $0.359 * *$ & 1.000 & & $0.300 * *$ \\
\hline Sig. (2-tailed) & 0.000 & 0.000 & & & 0.000 \\
\hline $\mathrm{N}$ & 380 & 378 & 380 & & 375 \\
\hline \multicolumn{6}{|l|}{ F4 Exploration } \\
\hline Correlation Coefficient & $0.291 * *$ & $0.312 * *$ & $0.300 * *$ & & 1.000 \\
\hline Sig. (2-tailed) & 0.000 & 0.000 & 0.000 & & \\
\hline $\mathrm{N}$ & 385 & 385 & 375 & & 387 \\
\hline \multicolumn{6}{|l|}{ Spending per person } \\
\hline Correlation Coefficient & 0.091 & $0.111 *$ & -0.012 & & 0.030 \\
\hline Sig. (2-tailed) & 0.086 & 0.037 & 0.832 & & 0.576 \\
\hline $\mathrm{N}$ & 357 & 354 & 340 & & 348 \\
\hline \multicolumn{6}{|l|}{ Age } \\
\hline Correlation Coefficient & 0.076 & $-0.154 * *$ & -0.039 & & $-0.113 *$ \\
\hline Sig. (2-tailed) & 0.139 & 0.003 & 0.455 & & 0.029 \\
\hline $\mathrm{N}$ & 380 & 377 & 363 & & 371 \\
\hline \multicolumn{6}{|c|}{ For how many people paying for } \\
\hline Correlation Coefficient & -0.023 & 0.010 & $0.303 * *$ & & 0.058 \\
\hline Sig. (2-tailed) & 0.658 & 0.849 & 0.000 & & 0.261 \\
\hline $\mathrm{N}$ & 383 & 380 & 366 & & 373 \\
\hline \multicolumn{6}{|l|}{ Gross Income } \\
\hline Correlation Coefficient & -0.051 & 0.044 & 0.070 & & -0.044 \\
\hline Sig. (2-tailed) & 0.457 & 0.515 & 0.312 & & 0.529 \\
\hline $\mathrm{N}$ & 217 & 217 & 208 & & 209 \\
\hline \multicolumn{6}{|c|}{ Overnight-visits over last three years } \\
\hline Correlation Coefficient & 0.052 & 0.007 & -0.089 & & $-0.143 * *$ \\
\hline Sig. (2-tailed) & 0.339 & 0.899 & 0.106 & & 0.009 \\
\hline $\mathrm{N}$ & 340 & 340 & 328 & & 332 \\
\hline \multicolumn{6}{|c|}{ How many nights for overnighting } \\
\hline Correlation Coefficient & $0.176^{* *}$ & $0.114^{*}$ & 0.044 & & 0.024 \\
\hline Sig. (2-tailed) & 0.000 & 0.025 & 0.393 & & 0.641 \\
\hline $\mathrm{N}$ & 390 & 387 & 372 & & 379 \\
\hline \multicolumn{6}{|c|}{ Age of first exposure to a National Park } \\
\hline Correlation Coefficient & 0.005 & $-0.151^{*}$ & -0.051 & & -0.061 \\
\hline Sig. (2-tailed) & 0.934 & 0.023 & 0.454 & & 0.364 \\
\hline $\mathrm{N}$ & 232 & 229 & 221 & & 223 \\
\hline
\end{tabular}

Another significant small relation is identified regarding the number of nights stayed in the park. The correlation coefficients of 0.176 and 0.114 indicate that the more nights visitors stayed in the park the more interested they are in terms of the 'Park attributes' and the motive 'Escape'. The visitors' age they were first exposed to a National Park also plays a role. Thus, a small significant relation can be identified due to the correlation coefficient of -0.151 . The younger are people exposed for the first time to a National Park the more motivated they are in terms of 'Escape'.

\section{Conclusion and suggestions}

Based on the results of the analysis the following findings and implications can be reported. Firstly, four motives were identified 'Park Attributes', 'Escape', 'Education \& Recreation' and 'Exploration'. By comparing these findings with previous studies on travel motives concerning national parks/nature areas the following becomes evident: The motivational factor 'Escape' got the highest mean value (4.0), followed by 'Education \& Recreation' (3.63) and therefore support the literature review (see Table 1) which revealed that 'Education/Learning about nature', 'Participation in recreation/Recreation or leisure pursuits' 
are the most frequently found motives of tourists to national parks/nature areas, followed by the motives 'Escape' and 'Relaxation'. Thus, tourists who are travelling to the Kgalagadi Transfrontier Park are in the first place motivated to get away from their every-day routine and to relax. By means of the limited numbers of accommodation, the geographically dispersed camps and the remoteness, the specific park already provides good opportunity to escape. Nevertheless, SANParks (the managing conservation authority) could use the tourists' high interest in 'escape purposes' for promotion by emphasizing the Park's unique characteristics as its remoteness and the opportunity to enjoy the open space without crowds of tourists.

The motive 'Education/ Learning about nature' was also identified in many other studies (Lili, Lijuan \& Ming, 2010; Slabbert \& Laurens, 2011; Line \& Costen, 2011) and supports the notion that tourists are motivated to learn about the Park and its animals and plants (Kerstetter et al., 2004; Kruger \& Saayman, 2010). Therefore, these results support Kruger and Saayman (2010) who recommended that SANParks should provide opportunities for tourists to learn about the irrespective parks by means of information boards, talks, videos, photographic displays, to name a few. This also includes that field guides and employees working in the park should be well-educated and able to inform tourists.

The motive 'Exploration' has the third highest mean value and with regard to the literature review it was not identified before and can therefore be seen as a unique motive to this park and study. Hence, tourists who travel to national parks and in this case to the Kgalagadi Transfrontier Park are interested in exploring a new destination and spending time with friends. Another reason for the explorative sense of tourists to this particular park can be seen in the fact that the park is relatively new with its opening in May 2000 and its size of $38,000 \mathrm{~km}^{2}$ implies that there is a lot to explore and many visits and time is needed for that. This motive goes along with the motive of education as exploring means to seek knowledge, to discover a new environment and to have new experiences. Therefore, SANParks should also invest in a good infrastructure and also provide maps indicating points of interest and attributes of the Park that could enhance the explorative sense of tourists.

By looking at the motives of this and other research, the quantity of different motives indicates that visitors to national parks/nature areas also differ in their motives and therefore SANParks has to analyze its target group to market it effectively and efficiently.

\section{Socio-demographic and behavioural aspects}

This second finding also confirms that a wide variety of social-demographic and behavioural variables influences the decision-making process and a diversified promotional strategy should be used. The following will suffice. It is important to use websites or SANParks itself for emphasising the exploration opportunities within the Park as people who use websites and SANParks as information source are especially motivated by the factor 'Exploration'. Furthermore, shows and programmes on television about the Kgalagadi Transfrontier Park should consider pointing out the unique park attributes as well as the possibilities of exploration, as people using these mediums as information source are predominantly motivated in terms of 'Park attributes' and 'Exploration'. Visitors using magazines as information source are more motivated by the factors 'Park attributes', 'Escape' \& 'Exploration'. Therefore, here it should be considered to integrate additional specific information within the magazines aiming at appealing to the tourists' explorative sense and simultaneously, to demonstrate the Park's uniqueness and relaxation opportunities. As people using previous visits as information source are more interested in 'Park attributes' and 'Education \& Recreation' Park management should consider to have a special, perhaps for loyal customers (wildcard holders), who still want to get to know more about the Park and its offerings. This knowledge seeking can be met through a wide variety of options for example check list of plants and animals, riddles with attractive prizes, educational programs and photographic opportunities and displays.

A third finding is the fact that tourists who are accompanied by their children have a high motivation to escape and to educate/recreate. This means, accommodation for families should provide facilities for relaxation and education as the parents probably aim at educating their children concerning the Park's nature and simultaneously, enjoying the relaxing and impressive environment.

The fourth findings carried out through ANOVAs indicated that in general international tourist scored on a lower mean value concerning the motivational factors than locals do. This, and the fact that Afrikaans and English speaking visitors of the Park are more motivated by the factors 'Park attributes', 'Escape' \& 'Education \& Recreation' demonstrate the heterogeneity of domestic and foreign tourists that should be considered for marketing purposes.

The Spearman's correlation coefficient also highlighted the fifth finding that more visitors spend while they stay in the Park the higher their motivation in 'Escape'. Therefore, Park management should provide relaxation facilities and should aim to hold on its remoteness and spaciousness, to foster that people evaluate the Park as appropriate travel experience to escape from everyday-routine. This is vital to the Park, as clients who have high expenditures during their stay in the Park are especially motivated by 'Escape' and in the meantime, they are highly profitable market. Another informative finding can be seen by the fact that the younger people are motivated by 'Escape' and 'Exploration' which should be considered within the Park management's marketing strategy, especially to draw younger tourists to the park. In addition, the more people the tourist paid for the higher were his/her motivation to educate and recreate. This means, that the Park management should provide special offers integrating educational aspects to larger travelling groups. Lastly a result from the Spearman's rho points out 
the longer tourists stay in the park the more interested are they in 'Park attributes' and 'Escape'.

\section{Conclusion}

The purpose of this article was to apply motivation based segmentation to tourists visiting Kgalagadi Transfrontier Park. This is due to growing competition as well as a lack of knowledge and understanding of the markets traveling to this unique park. This study makes several contributions, firstly, in terms of the discourse and the reasons why people travel to national or transfrontier parks or nature based areas. In addition the research clearly showed that the motives which requires park management to respond, especially in terms in the way they educate tourists, which implies interpretation or the lack thereof. It also shows that the park attributes cannot be left out of the equation and park management and SANParks specifically has to differentiate its marketing strategy. Exploration as a key motive was also found for the first time in this type of research, which is understandable seeing as this is a new park and it is large in size.

These findings demonstrate differences and preferences of visitor segments which should be considered to develop fine-tuned marketing strategies. Clustering the markets of the Kgalagadi Transfrontier Park in this way will allow focusing Park management's scarce resources on the most right markets and to compete in the market place.

The authors would like to thank South African National Parks (SANParks) and the National Research Foundation (NRF) for supporting this project.

\section{References}

Awaritefe, O.D. 2003a. 'Destination environment quality and tourist' spatial behavior in Nigeria: A case study of third world tropical Africa', International Journal of Tourism Research, 5(4): 251-268.

Awaritefe, O.D. 2003b. 'Destination image differences between prospective and actual tourists in Nigeria', Journal of Vacation Marketing, 10(3): 264-281.

Backman, K.F., Backman, S.J., Uysal, M. \& Sunshine, K.M. 1995. 'Event tourism: An examination of motivations and activities', Festival Management \& Event Tourism, 3(1):15-24.

Bansal, H. \& Eislet, H.A. 2004. Exploratory research of tourists' motivations and planning. Tourism Management, 25: 387-396.

Beh, A \& Bruyere, B.L. 2007. 'Segmentation by visitor motivation in three Kenyan national reserves', Tourism Management, 28: 1464-1471.

Crompton, J.L. 1979. 'Motivations for pleasure vacation', Annals of Tourism Research, 1(4): 408-424.

Crompton, J.L. \& McKay, S.L. 1997. 'Motives of visitors attending festival events', Annuals of Tourism Research, 24(2): 425-439.
Dey, B. \& Sarma, M.K. 2010. 'Information source usage among motive-based segments of travelers to newly emerging tourist destinations', Tourism Management, 31: 341-344.

Fodness, D. 1994. 'Measuring tourist motivation', Annuals of Tourism Research, 21(3): 555-581.

Goeldner, C.R. \& Ritchie, J.R. 2003. Tourism: Principles, practices, philosophies. Hoboken, NJ: John Wiley \& Sons.

Google Maps. 2013. Kgalagadi Transfrontier Park. [online] URL: $\mathrm{http}: / /$ maps.google.co.za/maps?hl=en\&q=kgalagadi + transfrontier + park + map\&bav $=$ on.2,or.r_gc.r_pw.\&bvm $=$ bv.41248874,d.d2k\&bi $\mathrm{w}=1024 \& \mathrm{bih}=665 \& \mathrm{um}=1 \& \mathrm{ie}=\mathrm{UTF}-8 \& \mathrm{sa}=\mathrm{X} \& \mathrm{ei}=-$ 4D_UKmcLcyRhQe724DoBg\&ved=0CAgQ_AUoAA

Hanks, J. 2003. 'Transfrontier conservation areas (TFCAs) in Southern Africa', Journal of Sustainable Forestry, 17(1-2): 127148.

Iso-Ahola, S.E. 1999. Motivational foundations of leisure. In: Jackson, E.L. and Burton, T.L. (Eds.). Leisure studies: Prospects for the twenty-first century. College State, PA: Venture Publishing.

Jang, S. \& Wu, C.E. 2006. 'Seniors' travel motivations and the influential factors: An examination of Taiwanese seniors', Tourism Management, 27: 306-316.

Johns, N. \& Gyimothy, S. 2002. 'Market segmentation and the prediction of tourist behaviour: The case of Bornholm, Denmark', Journal of Travel Research, 40(3):316-327.

Johnson, R.A. \& Wichern, D.W. 2002. Applied multivariate statistical analysis, 5th Edition. Upper Saddle River, NJ: Pearson Prentice Hall.

Jun, J., Kyle, G.T. \& Mowen, A.J. 2009. 'Market segmentation using perceived constraints', Journal of Park and Recreation Administration, 26(1): 35-55.

Keng, K.A. \& Cheng, J.L. 1999. 'Determining tourist role typologies: An exploratory study of Singapore vacationers', Journal of Travel Research, 37(4): 382-390.

Kerstetter, D.L., Hou, J.S. \& Lin, C.H. 2004. 'Profiling Taiwanese ecotourists using a behavioral approach', Tourism Management, 25(4): 491-498.

Kotler, P., Bowen, J. \& Makens, J. 2003. Marketing for hospitality and tourism, 3rd Edition. Upper Saddle River, NJ: Prentice Hall.

Krejcie, R.V. \& Morgan, D.W. 1970. 'Determining sample size for research activities', Educational and Psychological Measurement, 30:607-610.

Kruger, M. \& Saayman, M. 2010. 'Travel motivation of tourists to Kruger and Tsitsikamma National Parks: A comparative study', South African Journal of Wildlife Research, 40(1): 93-102.

Kruger, M., Saayman, M. \& Saayman, A. 2009. 'Sociodemographic and behavioural determinants of visitors at the Klein Karoo National Arts Festival', Event Management, 13(1): 53-68.

Lee, C.K. \& Lee, T.H. 2001. 'World culture EXPO segment characteristics', Annals of Tourism Research, 28(3):812-816. 
Lee, C.K., Lee, Y.K. \& Wicks, B.E. 2004. 'Segmentation of festival motivation by nationality and satisfaction', Tourism Management, 25: 61-70.

Lee, T.H. 2009. 'A structural model to examine how destination image, attitude and motivation affect the future behavior of tourists', Leisure Sciences, 31(3): 215-236.

Lili, P., Lijuan, C. \& Ming, W. 2010. 'Tourist behaviors in Wetland Park: A preliminary study in Xixi National Wetland Park', Hangzhou, China', Chinese Geographic Sciences, 20(1): 066-073.

Line, N. \& Costen, W. 2011. Environmental attitudes, motivation, and attachment: Toward a model of nature-based tourism. University of Massuchsetts - Amherst.

Lohmann, M. 2004. New demand factors in tourism. Institut für Tourismus- und Bäderforschung in Nordeuropa GmbH.

Loker, L. \& Perdue, R. 1992. 'A benefit segmentation of a nonresident summer travel market', Journal of Travel Research, 31(1): 31-35.

Lubbe, B. 1998. 'Primary image as a dimension of destination image: An empirical assessment', Journal of Travel and Tourism Marketing, 7(4): 21-43.

McDonald, M. \& Dunbar, I. 2004. Market Segmentation: How to do, how to profit from it. Oxford: Elsevier Butterworth Heinemann.

Mehmetoglu, M. 2007. 'Typologising nature-based tourists by activity - Theoretical and practical implications', Tourism Management, 28(3): 651-660.

Mill, R.C. \& Morrison, A.M. 1985. The tourism system: An introductory text. Prentice Hall, Englewood Cliffs.

Molera, L. \& Albaledejo, I.P. 2007. 'Profiling segments of tourists in rural areas of South-Eastern Spain', Tourism Management, 28: 757-767.

Oh, H.C., Uysal, M. \& Weaver, P.A. 1995. 'Product bundles and market segmentation based on travel motivations: A canonical correlation approach', Hospitality Management, 14(2): 123-137.

Pan, S. \& Ryan, C. 2007. 'Mountain areas and visitor usage motivations and determinants of satisfaction: The case of Pirongia Forest Park, New Zealand', Journal of Sustainable Tourism, 15(3): 288-308.

Park, D.B. \& Yoon, Y.S. 2009. 'Segmentation by motivation in rural tourism: A Korean case study', Tourism Management, 30:99108 .

Poria, Y., Butler, R. \& Airey, D. 2004. 'Links between tourists, heritage, and reasons for visiting heritage sites', Journal of Travel Research, 43(1): 19-28.

Qu, H.C. \& Ping, E.W.Y. 1999. 'A service performance model of Hong Kong cruise travellers' motivation factors and satisfaction', Tourism Management, 20: 237-244.

Saayman, M. 2006. Marketing tourism: Products \& destinations: Getting back to basics. 2nd Edition. Leisure Consultants and Publications, Potchefstroom.
Saayman, M., \& Saayman, A. 2009. 'Why travel motivation and socio-demographics matter in managing a national park', Koedoe, 51(1): $1-9$.

Saayman, M. \& Van der Merwe, P. 2004. Managing game farms from a tourism perspective. Institute for Tourism and Leisure Studies, Potchefstroom.

SANParks. 2012. Kgalagadi Transfrontier Park. [online] URL:http://www.sanparks.org/assets/docs/ebrochures/kgalagadi_o nline_brochure_2012.pdf

SA-venues. 2012. Northern Cape Game Reserves: Kgalagadi Transfrontier Park, Northern Cape. [online] URL: http://www.savenues.com/game-reserves/nc_kgalagadi-transfrontier-park.htm

Schneider, I.E. \& Backman, S.J. 1996. 'Crosscultural equivalence of festival motivations: A study in Jordan', Festival Management \& Event Tourism, 4: 139-144.

Slabbert, E. \& Laurens, M. 2011. Motivation-Based Clustering: An Empirical Study of Visitors to Kruger National Park in South Africa. In: 1st international conference on tourism and management sciences (ed JAC Santos) Algarve, Spain, 26-29 October 2011, pp1122-1126.

Swanson, K.K. \& Horridge, P.E. 2006. 'Travel motivations as souvenir purchase indicators', Tourism Management, 27: 671-683.

Tao, C.H., Eagles, P.F. \& Smith, S.L. 2004. 'Profiling Taiwanese ecotourists using a self-definition approach', Journal of Sustainable Tourism, 12(2): 149-168.

Tkaczynski, A. \& Rundle-Thiele, S.R. 2011. 'Event segmentation: A review and research agenda', Tourism Management, 32:426-434.

Uysal, M, McDonald, C.D. \& Martin, B.S. 1994. 'Australian visitors to U.S. national parks and natural areas', International Journal of Contemporary Hospitality Management, 6(3): 18-24.

Van der Merwe, P. \& Saayman, M. 2008. 'Travel motivation of visitors to the Kruger National Park', Koedoe, 50(1): 154-159.

Venter, P. \& Jansen van Rensburg, M. 2009. Strategic Marketing: Theory and applications for competitive advantage. Cape Town: Oxford University Press Southern Africa.

Wood, M.B. 2011. The Marketing Plan Handbook. 4th Edition. Upper Saddle River, NJ: Pearson Prentice Hall. 